\title{
NEOCONSTITUTIONALISM AND THEORY OF INTERPRETATION
}

\author{
Eduardo RIBEIRO MOREIRA ${ }^{1}$
}

Resumen:

El derecho constitucional ha sufrido muchos cambios después de la Segunda Guerra Mundial y sus consecuencias se han manifestado en otras áreas del derecho. Sin embargo, poca atención se le ha dado a la teoría jurídica después de estos cambios constitucionales. Este estudio investiga varios descubrimientos de estas implicaciones. Después de presentar lo que se entiende por neoconstitucionalismo, se avanza una correlación con los cambios en la interpretación constitucional. Un nuevo elemento - derrotabilidad - se presenta como una contrapartida necesaria entre la deliberación de los principios constitucionales y las enseñanzas de la teoría de las normas. Sólo a través de la derrotabilidad y el entendimiento de que la interpretación constitucional ha sufrido ciertos cambios, puede uno entender uno de los grandes postulados del neoconstitucionalismo.

Palabras clave:

Neoconstitucionalismo, interpretación constitucional, metodología constitucional, derrotabilidad.

1 Professor of Constitutional Law of the Federal University of Rio de Janeiro. Ph.D degree in Constitutional Law from PUC-SP. Visiting Researcher at the Castilla la Mancha University. Master's degree and Specialist degree in Law. Opinion Committee member in Rio de Janeiro.

Professor of Constitutional Law at the School of Judges of the State of Rio de Janeiro. 


\section{EDUARDO RIBEIRO MOREIRA}

Abstract:

Constitutional Law has undergone many changes since post World War II and its reflex has been felt in all other legal areas. However, little attention has been given to Legal Theory after these constitutional transformations. The present study discusses multiple aspects of such implications. After presenting what is understood by neoconstitutionalism, a correlation is drawn with changes in constitutional interpretation. A new element defeasibility - is then placed as a necessary counterpoint between deliberating constitutional principles and the theory of norms. Only if we take defeasibility into account and understand that constitutional interpretation has undergone certain changes, one is able to grasp the important tenets of neoconstitutionalism.

Keywords:

Neoconstitutionalism, Constitutional Interpretation, Constitutional Methodology, Defeasibility. 
Summary: I. A Presentation of Neoconstitutionalism. II. Potentialities of Neoconstitutionalism. III. In Neoconstitutionalism every Interpretation is a Constitutional Interpretation. IV. Measure of Interpretation: Integration of Interpreter with Method and with Case Type. V. Constitutional Interpretation and Methodology. VI. Neoconstitutional Interpretation and the Discovery of Defeasibility. VII. Conclusion. VIII. Bibliography.

\section{A Presentation of Neoconstitutionalism}

The theme expounded in this article was initiated while I was researching for my thesis "fundamental rights in times of neoconstitutionalism". Nowadays, many constitutional theories are being expounded as though they had been discovered on their own; nevertheless, they are part of a whole, i.e., of a legal structure that brings various common elements together in the same direction. The legal theory that converges with new constitutional interpretation. The pertinence of choosing this work is, therefore, not perfunctory in the least. Constitutional interpretation has both in-depth points and re-dimensioning with neoconstitutionalism. So much so that we can say, without any exaggeration, that the development of neoconstitutionalism will reveal the legal paradigm transformations is neoconstitutionalism.

It could be called contemporary constitutionalism or simply adopt the words 'new constitutionalism,' but we have opted to keep the common word adopted in continental-European Law. The expression 'contemporary constitutionalism' could lead to some misunderstanding, as one might think we were dealing with constitutional Law, when, in truth, the aim is much broader, a much more ambitious legal project.

The revolution in force today with the implementation of the Democratic Constitutional State of Law is based on constitutional Law, which, due to its unifying capacity and 
open meshwork enables progress to be made together with other branches of knowledge, especially with philosophy of Law. Due to this connection - philosophy of Law and constitutional Law - one can see in neoconstitutionalism a theory of Law that is both integrating and useful. Integrating, because it is not separate from policies, decisions, the society and moral ethics, all the elements present in cultural wisdom. In this new century, law makes a comeback as an expression of justice, only now with well-defined parameters of rationality, which allow us to delve into an axiological dimension within legal methodology.

Hence, the Law of the twenty-first century drifts away from the proposals of theories of Law, dominant up until then. In the first place, it is the opposite of positivism, in which it most leant on. As everyone knows, the structure of positivism was sustained by the separation of law and morals and politics (and because it did not do so with regard to economics, which did not play the role it does today). In the second place, it also moves away from the inconsistencies of jusnaturalism and the few points that it might be mistaken for, since neoconstitutionalism is founded on proposals that increment rationality, such as the celebrated deliberation. Finally, and in third place, legal realism and its sociological dimension are not left unattended in a proposal that acts upon the usefulness of Law.

The said usefulness is in fashion, for example, in the role that jurisprudence - especially constitutional jurisprudence - emanates as a source of the Law. In a positivistic classification, as the one found in art. 4 of LICC, jurisprudence would not be a true source of the Law; nevertheless, the customs and the analogy, minute practices in our legal tradition, would be secondary sources established in Law.

The sources of law connected to constitutional practices become much more disciplined under a theory of useful and integrative law. When speaking of jurisprudence and sources of law, we are moving towards a sense of globalization that belatedly arrived in law: the fusion of horizons. 
The US model, studying cases and the strength of precedents and effective legal mechanisms, of the primacy of the Supreme Court, has united with the continental European system, of foreseeing a number of fundamental rights, of strong and rigid constitutionalism and of the control of constitutionality abstracted from its laws. When law, in practice, put all these characteristics together, it was starting to give shape to a theory of law that would serve as a proposal for Western democratic countries.

Geographically speaking, it is not a general theory - as was legal positivism when first conceived - but, yes, it is an adequate theory for Western democracies ${ }^{2}$ with assumptions found in the so-called fusion of horizons (defense of fundamental rights, rigid constitution, mechanisms of separation of powers and of balances and counterweights, etc.). These can be understood as assumptions of neoconstitutionalism that appear, at the beginning of this century with strength and definition, as its temporal mark. It is quite true that its assumptions appeared after World War II, though they have developed since then, germinating into neoconstitutionalism, so baptized by several publications at the beginning of the twenty-first century.

\section{Potentialities of Neoconstitutionalism}

The unifying proposal presents itself first - and on this almost everyone who has written on the theme agrees - as a legal theory to be read based on constitutional Law, which is maximized by elements of philosophy of Law and political philosophy, which allows one to rethink legal foundations: the theory of norm, the theory of interpretation, the doctrine of sources and, lastly, the transformations that have occurred in several legal areas (constititutionalization of Law).

The theory of norm is no longer the same, after the study of rules, of principles and of procedural-legal criteria. That

2 And so, neoconstitutionalism also escapes the problematization over universalism vs. multiculturalism. 
which was based on the law and on its static studies has been totally transformed in neoconstitutionalism. Only the in-depth study of procedural-legal criteria (such as deliberation and coherence) and its repercussion in practice, point to a new path, quite distant from the one found in the theory of norm. This is but one example of this change.

The legal doctrine of sources has become even more distant. The principles, the last source in a positivized system - art. 4 of the LICC $^{3}$ - have now become the first source, historically speaking, to govern the law. Other studies, as that of norms of integration, lose importance to jurisprudence and to the irradiation of fundamental rights. And what can be said of the study of clashes between rules, now placed on a second plane with regard to conflict of principles - deliberation: one - and only one - more example of the referred to transformation.

The theory of interpretation gained different status when it was influenced by the philosophy of Law as: topic (a comeback to rethinking case studies based on problems they evoked), hermeneutics (and all the known methods of interpretation incremented by contemporary constitutional methodology) and legal argumentation (with regard to the justification of the interpreter), all integrated in neoconstitutionalism. From then on techniques are discovered such as defeasibility - and theories get better explained such as the one that says that every legal interpretation is, first and foremost, a constitutional interpretation. We will be studying these two points in greater detail further on.

Transformations occurring in various legal areas and placed under the subheading of neoconstitutionalism: the constitutionalization of law is in continual expansion. To exemplify, one could cite the possibility of deliberation in the penal system; the legal control of public policies and the effi-

3 Art. 4 of the Introductory Law to the Civil Code:

"When the Law is omissive, the judge will decide the case according to analogy, customs and the general principles of Law".

The order in which the subsidiary sources of law appear were related to a decreasing order that could not be inverted; typical position of positivistic thinking. 
ciency of administrative acts; the influences of community law on constitutional sovereignty; the answers to social issues given by civil constitutional law, a reality today. These stand, among various others, as examples of practical thematics integrated by neoconstitutionalism which, being practical and useful, has a better reading of society since the theories of traditional law alone are not enough to handle the theoretic complexity and new legal practices that have developed. Let us delve into just a few of these changes 4 :

\begin{tabular}{|c|c|c|}
\hline Theme & $\begin{array}{c}\text { How it is dealt } \\
\text { with in Traditional } \\
\text { Legal Theories }\end{array}$ & $\begin{array}{l}\text { How it is dealt with in } \\
\text { Neoconstitutionalism }\end{array}$ \\
\hline Society & Homogeneous & Plural and Global \\
\hline Morals & $\begin{array}{l}\text { Monistic, (with no } \\
\text { correlation to Law } \\
\text { in legal positivism) } \\
\text { or to Values (ab- } \\
\text { solute in } \\
\text { jusnaturalism) }\end{array}$ & $\begin{array}{l}\text { Constructivist, with Parameters of } \\
\text { Practical Rationality and Pretensions } \\
\text { of Correction, which will guide all legal } \\
\text { discourse and break with the existing } \\
\text { order. }\end{array}$ \\
\hline Policy & $\begin{array}{l}\text { Rule of Law (with } \\
\text { special attention } \\
\text { to coercion exer- } \\
\text { cised by the Judi- } \\
\text { ciary and to Pub- } \\
\text { lic Power acts) }\end{array}$ & $\begin{array}{l}\text { Constitutional State (allows special at- } \\
\text { tention to be given to emanations of } \\
\text { constituent and constituted Power - } \\
\text { constitutional reforms - and to the } \\
\text { role played by Constitutional Court. In } \\
\text { the foreground there is constant vigil } \\
\text { around fundamental rights, permitting } \\
\text { rights as a whole to reach a new sta- } \\
\text { tus.) }\end{array}$ \\
\hline \begin{tabular}{l|l} 
Institutional & \\
framework \\
of Legal \\
Sources
\end{tabular} & $\begin{array}{l}\text { Law in foreground } \\
\text { and remaining } \\
\text { sources held as } \\
\text { background }\end{array}$ & $\begin{array}{l}\text { Primacy of the Constitution and of Ju- } \\
\text { risprudence emanating from Constitu- } \\
\text { tional Court. }\end{array}$ \\
\hline $\begin{array}{l}\text { Theory of } \\
\text { Norm }\end{array}$ & $\begin{array}{l}\text { Set of Norms with } \\
\text { configurations of } \\
\text { rules }\end{array}$ & $\begin{array}{l}\text { Primacy of principles completed by le- } \\
\text { gal argumentation. Existence of politi- } \\
\text { cal norms and of procedural legal cri- } \\
\text { teria, in addition to rules and princi- } \\
\text { ples with peculiar morphology. }\end{array}$ \\
\hline
\end{tabular}

4 These changes have been noticeable over the last 50 years; this table was organized to a large extent during talks with Alfonso Figueroa. 


\begin{tabular}{|l|l|l||}
\hline $\begin{array}{l}\text { Theory of } \\
\text { Interpreta- } \\
\text { tion }\end{array}$ & $\begin{array}{l}\text { Rules for interpre- } \\
\text { tation and when } \\
\text { these are non-ex- } \\
\text { istent, the inter- } \\
\text { preter is free to } \\
\text { judge. }\end{array}$ & $\begin{array}{l}\text { Refined constitutional methodology, } \\
\text { considering values and creating con- } \\
\text { terpretation is constitutional interpre- } \\
\text { tation. }\end{array}$ \\
\hline $\begin{array}{c}\text { Theory of } \\
\text { Law }\end{array}$ & $\begin{array}{l}\text { Positivism (exclu- } \\
\text { sive or inclusive) }\end{array}$ & Neoconstitutionalism \\
\hline
\end{tabular}

According to this construct, neoconstitutionalism as a theory of Law can be understood as the paradigm that reviews the theory of norm, the theory of interpretation, the theory of sources, supplanting positivism to integrate it under a useful and transforming base, having traversed theoretic and practical transformations in various legal areas.

The claim to transformation could sound exaggerated if one were to consider only that which has been under separate debate. Neoconstitutionalism, however, does not end as a proposal of a theory of law, for it also deems to be a proposal of philosophy of law and a proposal of political theory $^{5}$. It is in the latter two that the ambition of neoconstitutionalism is revealed and where innumerable divergences appear. Many only see the possibility of neoconstitutionalism as a theory of law and do not want law to invade the realm of morals or politics. There are many contrary arguments, but all spring from the maculation of there associations ${ }^{6}$ and of theoretic ambiguity ${ }^{7}$.

At the other end of the scale, those who support the integration of the theory of law to the other two potentialities seen in ultimate neoconstitutionalism - of political philosophy and of philosophy of law -, do so in the hopes that law

5 To see a near classification, though with themes debated in Europe - tripartite neoconstitutionalism is broken up into theory of Law, political philosophy and theory of state - see Antonio Maia, "As Transformações dos Sistemas Jurídicos Contemporâneos: Apontamentos acerca do neoconstitucionalismo" (Transformation of Contemporary Legal Systems: Notes on neoconstitutionalism).

6 Prieto Sanchís, Luis, Justicia constitucional y derechos fundamentales.

7 Pozzollo, Suzana, Un constitucionalismo ambiguo. 
might supersede frontiers never before cultivated in depth by the other theories of law. These authors do nothing but maximize the postulates of connection between law and morals - in neoconstitutionalism as a philosophy of law and the connection between law and politics - in neoconstitutionalism as a political philosophy. From then on, the field to be explored is truly vast.

Examples of neoconstitutionalism as a philosophy of law would remain to supplant the studies of merely descriptive and prescriptive norms; in the role of the legal scientist as external observer; in the separation between law and morals (be it total or contingent); finally, in everything that represents law exclusively as it really is. It disconnects itself as well from law as it should be, from subjective morals, from the philosophy of values and from extra-legal sources. The philosophy of law of neoconstitutionalism concerns itself: with the legal scientist linked to what is happening around the world; with concrete derivations of law; with the connectedness of law through parameters of rationality and inter-subjectivity; with the necessary relationship between morals and politics, both guided by a claim to correctness; with law being evaluated by criteria of coherence and proportionality; with law exposed by solid theory of argumentation, and so after all with law that reaches up to higher degrees in which it can be. All these key concepts reconstitute main research studies in philosophy of law also integrated by neoconstitutionalism which give them a useful destination $^{8}$ seen, first and foremost, in the application of the judicial phase ${ }^{9}$. Bearing all this in mind, neoconstitutionalism in the philosophy of law dimension is attractive both to lawyers enchanted with philosophy and to philosophers with an inclination for law.

8 On doing this, neoconstitutionalism withdraws one of the main weights from philosophy of law, the unlikely accusations of its meager practical applicability.

9 Not that this is exclusively a concern of the law, since the legal production phase - up to the pre-constitutional phase- should be cared for by neoconstitutionalism, above all in the branch of political philosophy. 
But neoconstitutionalism as a political philosophy redefines the role of the elements of state in a cosmopolitan world; it also reflects the impact of constitutional decisions on the population in a special way, popular participation that sometimes surges from a (still rising) constitutional culture, already elaborated as constitutional feeling or patriotism. Elements of State, from the representativity crises, continental blocks and multiculturalism, all is debated within and based on constitutional bias in the political philosophical dimension of neoconstitutionalism ${ }^{10}$.

Within these multiple research hypotheses, let us for now focus on one in particular, which represents one of the first and most important developments in neoconstitutionalism: the theory of interpretation.

\section{IN NEOCONSTITUTIONALISM ALL INTERPRETATION IS CONSTITUTIONAL INTERPRETATION}

The first of the elements to appear was over-interpretation (which is the same as the interpretation of laws based on the Constitution, on neoconstitutionalism), which can be understood as the interpretation in neoconstitutionalism ${ }^{11}$. It was the production of constitutional hermeneutics that shaped the real structures of power into jusfundamental constitutional matter and sustained the development of avant-garde constitutional production. The evolution of constitutional interpretation, heavily marked over the last 60 years, has not halted in time, as it continues to expand as a key element in critical legal thinking. The principles deployed a large portion of this transformation, before the last subsidiary source, now the main source, ruling

10 We can also see this in a different light, since thinking within the present framework, the philosophy of law or even the philosophy of politics disassociated from constitutional law would be like not knowing where legal issues spring from, which would be the same as not "knowing what Philosophy of Law is today". $C f$. Cattoni, Marcelo, Direito política e filosofia, p. 136.

11 As opposed to the thesis of interpretation promoted by legal positivism. $C f$. Prieto Sanchís, Positivismo y constitucionalismo, p. 37. 
over the application of laws. This is why each and every legal norm - not just the laws, but their completion, jurisprudence - should be conditioned to over-interpretation of jusfundamental principles. This is the most important characteristic of the process of constitutionalism in law, in sum, the "theory of interpretation based on the Constitution seems no longer to be able to remain the same as the theory of interpretation based on law: constitutional norms stimulate another type of legal reasoning ${ }^{12}$."

The theory of constitutional interpretation and the control techniques of constitutionality blend with one another in the exercise of constitutional jurisdiction, especially in the task of judging the constitutionality of law and in the interpretative task regarding fundamental rights.

Interpretation in neoconstitutionalism has an even broader meaning. Every legislative ${ }^{13}$ or judicial ${ }^{14}$ decision is pre-regulated by constitutional norm. Legislative production, as everyone knows, is open to the control of constitutionality, the moment in which constitutional interpretation most manifests itself 15 .

But the phenomenon that occurs with interpretation in the application of judicial phases shows that all legal interpretation - direct or indirect - is constitutional interpretation, so that there are no empty spaces left behind.

The connection of the constitutional text as a work of interpretation comes about (1) directly, when judicial decision is based on a principle or on any constitutional norm applied to a case - expressly mentioning constitutional precept. That is when Constitution is actualized.

$12 C f$. Prieto Sanchís, Luis, Constitucionalismo y positivismo, p. 22.

$13 C f$. Guastini, Riccardo, La constitucionalización del ordenamiento jurídico: el caso italiano, p. 54.

$14 C f$. Barroso, Luis Roberto, Prefácio - O Estado Contemporâneo, os Direitos Fundamentais e a Redefinição da Supremacia do Interesse Público, p. XII-XIII.

15 It is well to remember the performance of the constitution and justice committee, of the veto of the nation's President based on a law which is contrary to the Constitution and of all the other instances that the Constitution is invoked to obstruct or redirect a bill. 
Interpretation is indirect in two instances. Initially, through a negative, ever present judge, which occurs when no mention is made of unconstitutionality, which means that the legal mechanism that substantiates the decision has successfully passed through the hands of a negative judge; in confrontation with constitutional norms, the legal mechanism, the basis for the decision, survived - it is not incompatible with the Constitution -, judgment prior to the very examination of concrete merit.

In the second instance, constitutional interpretation is indirect, according to a finalistic judgment, since all decision should abide by the constitution and be guided by the goals expressed therein. In theory, all decision should be guided by compliance with constitutional ends. As in the Brazilian case concerning the dignity of the human being and the reduction of social inequality, which appear respectively as structural principles and national goals and which should frame the results of legal productions.

From these three exercises in hermeneutics - the direct, the negative indirect and the finalistic indirect - one reaches the inescapable conclusion that all legal interpretation is first and foremost constitutional interpretation.

\section{MEASURE OF INTERPRETATION: INTEGRATION \\ OF INTERPRETER WITH METHOD AND WITH CASE TYPE}

The marked breakthrough in constitutional interpretation allows one to develop theories and constructivist constitutional methodology capable of responding to the needs of social relationships, which shows the degree of integrity of interpretation found in neoconstitutionalism.

It is while placing one's trust in the interpretative capacity of constitutional text, with transforming power, that the framework of the principles proves itself to be open to completion and to gradations. The Constitution, with room for its conformation, leads to optimization of the constitutional text due to the capacity of the interpreter to make better use of rights, without excesses. 
It is interesting to consider over-interpretation with regard to what one understands by fundamental precept. As everyone knows, it is not the same as fundamental right, for it would not make sense to attribute two terminologies with univocal meaning. There are those who maintain that fundamental precepts, to be protected by the action of noncompliance, are all the Petra clauses, in addition to all the remaining fundamental rights and sensitive principles ${ }^{16}$. This is a good starting point, but one which cannot remain closed, affirms Nagib Slaibi, who leaves the demarcation of what is a fundamental precept up to constitutional interpretation ${ }^{17}$, because such content is topical and can change with time - what is not fundamental today can be so considered in the future, in a true constitutional mutation. The expression fundamental precept contains minimum content, but its demarcation is completed by means of (neo)constitutional over-interpretation.

However, the so-called fundamental constitutional precepts brought the discussion about the importance of constitutional norms over to Brazilian dogma, bringing about a guided distinction, not in terms of internal structure, but in terms of relevance (external, axiological) of constitutional norms ${ }^{18}$.

The fundamental precept is quite connected to the fundamental protection of the minimum existential that the State must guarantee at whatever cost - much of which could not make up concentrated control, as those from municipal law, or from laws prior to the constitution. This is the task of the interpreters of the Constitution. The role of the interpreter rose to greater importance after the work accomplished by legal argumentation, which certifies whether the options made by the interpreter are in accordance with the p. 291.

$16 C f$. Peña de Morais, Guilherme, Direito constitucional - Teoria da Constituição,

$17 C f$. Slaibi, Nagib, Direito constitucional, p. 338.

$18 C f$. Tavares, André, Fronteiras da hermenêutica constitucional, p. 97. 
produced justification. Constitutional hermeneutics, on the other hand, verifies the methodology and applied procedures being used. It can be noted that one does not improve without the other; more than ever, hermeneutics and legal argumentation should be studied in combination, since justification, represented by the interpreter and the interpretative process, represented by the constitutional methodology relevant to the case, are complementary. To them is added the problem, i.e., the type of case that is to be judged. The type of case studied based on the problem presented, passing by solutions already presented and eliminating those that do not pertain, is typical of topical thinking. Such reasoning, common in the United States, has gained importance since the topical and, with the fusion of horizons, has joined our legal system, ascertainable by the rising interest in precedents. The type of case, the interpreter and his argumentation and the method absorbed, respectively, with the passage of time, elements of philosophy of law, such as the topical, legal argumentation and hermeneutical philosophy.

The moments of constitutional deliberation are more important for many than the moments of formal change from the constitutional text, as these extraordinary moments result in constitutional transformations that should be adopted by the Courts. ${ }^{19}$ More than ever, cases that had been judged by the Supreme Federal Court are now being studied using quite varied assessments. Today the task of interpreting law is so linked to the Constitution and to the figures of its interpreters that one hardly speaks about legal hermeneutics, but about constitutional interpretation.

\section{INTERPRETATION AND CONSTitutional Methodology}

Constitutional hermeneutics is the very field of studying the task of interpretation. The opening of the constitutional

19 Cf. Ribas Vieira, José, Teoria da mudança constitucional, p. 92. 
text buried, once and for all, the notion that only the legal text that was not clear should be interpreted ${ }^{20}$. Each and every norm carries with it, directly and potentially, the element of disposition to be interpreted in light of the Constitution. The task of interpreting - that of getting a better understanding of the text -, is equivalent to the task of applying the law ${ }^{21}$. They are not two separate moments, as had been originally thought in studies of classical hermeneutics.

The completion process of constitutional text under philosophical analysis is nothing but the closure of the hermeneutic circle, and not indetermination as one had been led to believe. The completion of constitutional norm ${ }^{22}$, before being studied as constitutional methodology 23 , should be seen as the end of the interpretative activity better explored in neoconstitutionalism.

The methodology behind the works of constitutional interpretation, though no longer at the center of the constitutional debate, deserves special consideration and adequacies. There are no final rules for correct use of constitutional methodology; that would be an exaggerated methodological over-plan, in which too much importance would be given to knowledge of methodologies that would be in an over-plan, aside from the substantial law, the principles and constitutional norms that, in turn, still have to be correlated to the facts, by legal argumentation, by procedural norms and other multi-disciplinary knowledge, case by case; truly a task for a Herculean judge ${ }^{24}$. These complete studies should be required of judges and representa-

$20 C f$. Konrad Hesse, comments on the need for constitutional interpretation every time that the Constitution does not provide within itself a concludent answer. $C f$. Hesse, Konrad, Escritos de derecho constitucional, p. 35.

21 Cf. Gadamer, Hans, Verdade e Método I, p. 406.

22 Cf. Gomes Canotilho, Direito constitucional, p. 1221.

$23 C f$. Hesse, Konrad, A Força normativa da constituição, p. 58.

24 In the sense of Herculean judge, used by Ronald Dworkin in Taking Rights Seriously. 
tives in Supreme Courts and in lesser Courts, in the solution of difficult and tragic cases.

The methodologies of interpretation should be adjusted to the theory of rights, adopted to eliminate, from then on, any incoherence amongst them. In this regard, they can very well be different methodologies applied to the same context, or even to the same case (whenever the decision is made by a collegiate body). A good example is the application of the principle of constitutional unity, which preaches coherence and integrated reading of constitutional norms, on the one hand, with the deliberation, which is the criterion $^{25}$ (for many, the $\operatorname{method}^{26}$; for others, the principle ${ }^{27}$; for still others, the rule ${ }^{28}$ ) to the solution of the conflict between constitutional norms. In a more traditional constitutional interpretation, coexistence between the two methodologies ${ }^{29}$ was not held as possible ${ }^{30}$, or at least, as

25 In the sense of understanding as a postulate, cf. Humberto Ávila, Teoria dos Princípios, already as a criterion of Legitimation, thesis defended by Ricardo Lobo Torres, approaches the idea of procedural criterion, without a content of its own.

26 Cf. Gomes Canotilho, Direito constitucional.

$27 C f$. Roberto Barroso, Luis, Interpretação e aplicação da constituição.

28 Cf. Reis, Jane, Interpretação constitucional e direitos fundamentais, p. 362.

29 We continue to view the deliberation of interests as a procedural-argumentative criterion, though in practice it is very often seen as a method of constitutional work, in addition to being contested, many other times, as a constitutional principle. What matters is that it should be used correctly, working with its phases -, sub-principles of deliberation -, its argumentative completion, the verification of fundamental rights that really exist and not just alleged out of thin air. The study of parameters to limit exaggeration in deliberation and the actual possibilities of confrontation complement the theory. The reading of Alexy seems to structure legal norm along three guidelines, since besides principles and rules, there appear procedural criteria, as for example the deliberation itself or universality. This valuable tripartite division of norm is one of Alexy's most precious contributions, even if he did not include the policies - norms of public policies- for us absolutely essential for considering the norm in four phases: principles, rules, public policies and procedures inherent to them.

30 Towards this end, it is worthwhile seeing Konrad Hesse's critique with regard to the meeting between constitutional unity and deliberation between conflicting constitutional norms (a Força Normativa da Constituição, p. 49). At the time Hesse wrote about deliberation, held by him to be a constitutional methodology, it had not yet been developed and applied as was later the case to the works developed by Alexy and his followers. The status obtained after the publication of the Teoria de los derechos fundamentales, reformulated the application of the institute, 
questionable. When one seeks to criticize the use of constitutional methodologies, unity and deliberation are pointed out as being determinately antagonistic, which does not correspond to the potentiality of the two methodologies. This can be explained by the theory of constitutional law, which reveals the conception of limits of constitutional effectiveness at a given moment. According to the theory of restrictive and certainly positivistic law such methodologies are not capable of coexisting within the ordination. On the other hand, today, in a neoconstitutional conception, constitutional deliberation and unity coexist harmoniously, the two even working together in the same concrete case, without any setback whatsoever. Constitutional-methodological purism is neither a part of the Luso-Brazilian tradition nor does is necessarily result in legal improvement.

Canotilho, for example, when dealing with the interpretation of constitutional norms, goes to the other extreme by listing all the methodologies found by other authors, adding dimensions of the topical, of legal argumentation, of legal sociology (spiritual-scientific method), of the structure of language, together with the pragmatic, and, furthermore, adding a catalog of principles of constitutional interpretation, mixing them in with constitutional assumptions - as the normative force of the Constitution, constitutional fairness or the supremacy of the Constitution -, at any rate, a mixture that reveals that much of the knowledge about constitutional interpretation can be transformed into work methodologies, as an adaptation of the interpreter.

Neoconstitutionalism does not defend criteria of methodological scientificity, not does it shun it. The erudition surrounding the various constitutional methodologies increases the capacity to find the means to translate the normative force of the Constitution and constitutional will as respectfully as possible. To use only classical methods grammatical, historical, systemic and teleological interpre-

seen with different eyes, which, in turn, fully collaborated with the instauration of the current moment in neoconstitutionalism. 
tation results in limiting the range of action of the interpreters. The choice of method translates the preferences of the interpreter even as to other areas of knowledge, such as history, sociology, philosophy and economics, among others, which fit, respectively, as a suggestion, in the following methodologies: historical, spiritual-scientific, topical and consequential pragmatist. The most prepared interpreter of the Constitution should make use of the more apt methodologies to defend the constitutional text and make it effective. In multidisciplinary matters, as those that come up before the Supreme Federal Court, correct knowledge of various constitutional methodologies will represent valuable support when opting for the best decision from amongst those possible. Multiple methodologies are not bad in themselves, but their distorted and abusive use can result in interpretative misreading.

A necessary notice: methodologies should be argumentatively justified, and, when in a similar case another constitutional methodology is adopted, out of respect for the principle of universality ${ }^{31}$ and coherence, the new option should be expressly justified, as it might lead to a mutation of constitutional jurisprudence. Fidelity to the methodology repeatedly used in similar cases and justification of the greater argumentative load in line with the use of new methodologies are much more important, in the exercise of the forensic practice, than creating new methodologies of interpretation.

One of the reasons why constitutional methodology has lost the hegemony of legal discourse has been the perception that various methodologies can lead to the same result - although this does not often occur - and, what is more, the same decision that does not expressly mention the constitutional methodology used, when analyzed by different interpreters, can point to distinct methodological readings of the same text. Thus Gadamer fittingly reasons when he claims that, once written, the text no longer belongs to the 
author, since it now "speaks" to the interpreter. This much one can see in books, articles, judgments that, often is the case, gain momentum to go beyond - when not diversely from - the original desire of the author ${ }^{32}$.

Over-interpretation of the Constitution -, with this wide range of existing methodologies -, to be exercised with liberty and responsibility, is defended at a stage of high constitutional development. In neoconstitutionalism this stage is reached by making correct use of procedural-argumentative criteria, such as reasonability, proportionality, coherence and universality, not only in merit and in procedural law, but also in the debate over constitutional methodology, above all, when it is different from the one ordinarily used, badly applied, or of doubtful context. Such debate closes a constitutional cycle of the highest order, as has already been observed in the Supreme Court of the United States.

\section{NEOCONSTITUTIONAL INTERPRETATION AND THE DiscoverY of DEFEASIBILITY}

An important theme identified with constitutional interpretation, interpretation according to the Constitution, deserves amplification and (three) possibilities of use in neoconstitutionalism. Such use will be of great applicability in Brazilian constitutional law. One can thus see the possibilities of interpreting the law in light of the Constitution.

It is, indubitably, polysemic terminology and little explored - interpretation according to the constitution - at least in its other two meanings. To begin with, some understand that it is but a control technique of constitutionality, while others allege that it is first and foremost a matter of constitutional interpretation. As to the impropriety of iden-

$32 C f$. Gadamer, Hans, Verdade e Método II, p. 507. It is worthwhile highlighting that Gadamer, if not for the historical moment in which he lived, is a great critic of the importance of the method, i.e., of the methodological exaggeration that used to impregnate the sciences, especially hermeneutics. Cf. Verdade e Método I, p. 29 e Verdade e Método II, p. 389. 
tifying the interpretation according to the Constitution as a rule of constitutional interpretation, André Tavares states:

Interpretation according to the Constitution would be better understood as being a work method developed within the activity of constitutionality control rather than as being one more purely interpretative formula. ${ }^{33}$

Luis Roberto Barroso understands differently, for he considers interpretation, first and foremost, as a constitutional interpretation technique. The author alleges that any interpretation that holds the Constitution as parameter is a constitutional interpretation, and thus, when excluding interpretations of one mechanism, the Constitution remains the true source of validation.

For neoconstitutionalism, interpretation according to the Constitution has three meanings and the first is literal, i.e., interpreting laws in light of the Constitution. This meaning has been forgotten, and mistakenly so, since the mention of a mechanism in light of its constitutional direction remains interpretation according to the Constitution, even though the only one extractable from the norm. The opposite would be to deny the linguistic meaning of the expression: that every law should pass under the scrutiny of constitutionality, or, as was stated earlier, under an indirect negative judgment. This often imperceptible and non-expressed exercise is interpretation according to the Constitution. The doctrine, however, only recalls the second meaning.

The second meaning relates to interpretation as it occurs when more than one interpretative hypothesis is present, the moment in which the competent court declares which of them is most appropriate in view of the constitutional text. It is one way of saving legal norm and firming constitutional guidelines. This is usually the meaning given by Brazilian doctrine and jurisprudence. Examples can be construed in law that have more than one interpretative 
possibility, when the courts point to which interpretation is unconstitutional - and, hence, can no longer be endorsed thus saving the content of the norm. The written norm is preserved and an interpretation is prohibited. A good example in Brazilian Law occurred with the promulgation of the Statute of the Elderly. Articles 75-77 regulated the necessary participation of the Prosecutor's Office in all cases in which a person over the age of 60 were taking part. ${ }^{34}$ This would incur in losses for the Prosecutor's Office and would slow down all the cases in which senior citizens were involved. When passing judgment on this matter, the Supreme Federal Court decided that what was needed was to interpret the cases according to the Constitution, the precepts - art. 75-77 of the Statute of the Elderly -, to give meaning to the intervention on the part of the Prosecutor's Office only in disputes where senior citizens found themselves to be unprotected or in need of special attention. The rules remained preserved, only the interpretation that deemed the participation of the Prosecutor's Office necessary on any occasion with senior citizens could no longer be applied.

The third meaning of interpretation according to the Constitution is seen only in concrete cases, when, exceptionally, the effects of the rule are withdrawn due to a situation exceptionally not foreseen (post factum). The third use of interpretation according to the Constitution is synonymous of defeasibility of the rule-norm, which works as dispositional property arising in neoconstitutionalism. Recalling the lessons of Alfonso Figueroa, dispositional property is not man-

34 Lei num. 10.741/2003: Art. 75. In cases and procedures in which it is not taking part, the Prosecutor's Office must act in defense of the rights and interests of those whom this law pertains to; hypotheses in which it will view the files after testimony of the parties, being able to add documents, request diligence and production of evidence, using pertinent resources.

Art. 76. Subpoena from the Prosecutor's Office, in any case, will be served personally.

Art. 77. Lack of intervention on the part of the Prosecutor's Office will incur in annulment of proceedings, which will be declared official by the judge or by a solicitation from any interested party. 
ifest in full, only when given certain post factum circumstances can it manifest itself. It is different from categorical property, which is immanent, automatic and full and will always manifest itself. The dispositionality of principles has been contested, and insofar as that goes, there is no doubt as to its opening and gradation. What we defend, however, is allowing it to go further with dispositionality of rules. It has always been said that they are either worth all or nothing and that they are not decided by deliberation, and this still holds true. It so happens that rules in exceptional situations, that do not fulfill the constitutional aim or finality, should be defeated, and as a consequence, should be removed from the concrete case so as not to form jurisprudence.

This is one of the great breakthroughs sustained by neoconstitutionalism, as it sets aside the exceptions that combat deliberation, especially for those that claim a (mis)conception that rules are resolved by deliberation. This reasoning - that rules are resolved by deliberation - arising from deconstructive analytic philosophy, actually aims at eliminating the use of deliberation and limiting constitutional principiology. They are, in fact, exceptional examples, brought to light to sever with the order of deliberation, with the principles of neoconstitutional logic. But in truth, these examples bear the weight of defeasibility and are stored in the theory of neoconstitutionalistic law within the third meaning of the interpretation according to the constitution. Defeasibility or the third meaning of interpretation according to the constitution maintains the workings of the (neo)constitutional system without any hitches. Many claims to delegitimate deliberation, as those made by Humberto Avila, in Brazil, 35 or the examples brought by Frederick Schauer, 36 fall flat. They are, truth be told, hypotheses of defeasibility of the norm.

35 Cf. Ávila, Humberto, Teoria dos Princípios.

$36 \mathrm{Cf}$. Schauer, Frederick, Playing by the rules. 


\section{CONCLUSION}

The path trod for the construction and acceptance of a theory of law is no easy matter. The herein exposed reconstruction presents neoconstitutionalism as the theory of law most akin to the legal proposals existing in Brazil. In one stroke it gives critics of the general theory of law an option, providing them with a useful law proposal, one that satisfies the anxieties of the society of presenting laws capable of transforming, and that unite hitherto scattered construction of doctrine and of constitutional jurisprudence, making up an integrated proposal. Moreover, the merely cited potentialities of neoconstitutionalism unfold into fascinating research possibilities. It was high time constitutional law was seen in light of its connection to philosophy.

We have highlighted in this paper the revitalized role of interpretation with regard to neoconstitutionalism, which is significant, as it attests to the capacity of interpreters of the nation's Constitution, removes itself from legal positivism which seals any interpretation outside of the framework and of jusnaturalism - that seeks values outside the system - occasioning a pretension to correction.

Materialization of transformations in interpretation occurs at the moment of application, legitimation and anchoring of its practical elements. Neoconstitutionalism postulates an interpretation of the Constitution at every moment since all legal interpretation is constitutional interpretation, as has been fully demonstrated, be it in direct or in indirect moments (negative and objective).

The theory of interpretation cannot be seen with fragmented vision, because the interpreters - of an open and axiological constitution - should be on an equal footing with the methodologies, the case and the precedents being considered. All these interpretative elements should be integrated by the philosophy of law.

Defeasibility should be diffused as a key concept that affects the practice and imposes revision of critiques directed 
at the use of a pro-principles theory. Defeasibility or the third form of interpretation according to the constitution, begins to be developed, and has the impetus to reach constitutional courts.

It remains to be said that everything stated herein has been based on an existing legal content, contextualized within the Constitution, and that ultimately it is enough to disclose and apply the Law correctly.

\section{BIBLIOGRAPHY}

AlEXY, Robert, Teoria da Argumentação jurídica, São Paulo, Landy Editora, 2001.

_- Teoría de los derechos fundamentales, Madrid, Centro de Estudios Constitucionales, 2002.

ÁvIlA, Humberto, Teoria dos princípios, 3a. ed., São Paulo, Malheiros, 2003.

BARROSO, Luis Roberto, Interpretação e aplicação da Constituição, 2a. ed., São Paulo, Editora Saraiva, 1998.

__ , "Prefácio: O Estado Contemporâneo, os direitos fundamentais a redefinição da supemacia do interesse público", Interesse Público vs. Interesse Privado, Rio de Janeiro, Lumen Juris, 2006.

CANotilho, J. Gomes, Direito constitucional e teoria da Constituição, 2a. ed., Coimbra, Editora Almedina, 1998.

CATTONI, Marcelo, Direito politica e filosofia, Rio de Janeiro, Lumen Juris, 2007.

CAVAlCANTI MAIA, Antonio, “As transformações dos sistemas jurídicos contemporâneos: apontamentos acerca do neoconstitucionalismo", Revista do Direito do Estado, num. 5, Jan-Mar 2007.

GARCÍA FigueroA, Alfonso, "La teoria del derecho em tiempos del Neoconstitucionalismo”, in CARBOnELL, Mi- 
guel (coord.), Neoconstitucionalismo(s), 2a. ed., Madrid, Trotta, 2005.

GADAMER, Hans-Georg, Verdade e Método II, Petrópolis, Editora Vozes, 2002.

_, Verdade e Método I, 5a. ed. Petrópoli, Editora Vozes, 2003.

GUASTINI, Riccardo, "La constitucionalización del ordenamento jurídico: el caso italiano", in CARBOnELL, Miguel (coord.). Neoconstitucionalismo(s), 2a. ed., Madrid, Trotta, 2005.

Hesse, Konrad, A força normativa da Constituição, Porto Alegre, Sergio Antonio Fabris, 1991.

, Escritos de derecho constitucional, Madrid, Centro de Estudios Constitucionales, 1983.

PEÑA DE MORAES, Guilherme, Direito constitucional-Teoria da Constituição, Rio de Janeiro, Lumen Juris, 2003.

PEREIRA REIS, Jane, Interpretação constitucional e direitos fundamentais, Rio de Janeiro, Editora Renovar, 2006.

Pozzolo, Susanna, "Un constitucionalismo ambiguo", in CARBONELL, Miguel (coord.), Neoconstitucionalismo(s), 2a. ed., Madrid, Trotta, 2005.

PRIETRO SANCHÍs, Luis, Positivismo y constitucionalismo, México, Ed. BEMP, 1999.

_- Justicia constitucional y derechos fundamentales, Madrid, Trotta, 2003.

RAMOS TAVARES, André, Fronteiras da hermenêutica constitucional, São Paulo, Método, 2006.

SCHAUER, Frederick, Playing by the Rules, Claredon Press, Oxford, 2002.

SlaIBI, Nagib Filho, Direito constitucional, Rio de Janeiro, Forense, 2004.

VIEIRA RIBAS, José (org.), Teoria da mudança constitucional, Rio de Janeiro, Renovar, 2005. 